\title{
Comparison between dexmetomidine and midazolam on early extubation and hemodynamic profile. a randomized double-blind study
}

\author{
M Mavri ${ }^{1}$, K Rellos ${ }^{1}$, I Pantazopoulos ${ }^{2}$, C Kampolis ${ }^{3}$, I Floros ${ }^{4}$, N lacovidou ${ }^{5}$, T Xanthos ${ }^{6}$, C Pantazopoulos ${ }^{4}$ \\ From ESICM LIVES 2015 \\ Berlin, Germany. 3-7 October 2015
}

\section{Introduction}

Patients under mechanical ventilation in the Intensive Care Unit (ICU) require sedation in order to facilitate ventilator and endotracheal tube tolerance. The sedative agent that must be used should not interfere with early extubation of patients. Midazolam is a benzodiazepine, a common sedative agent used in the ICU, while dexmetomidine is an alpha 2 adrenergic receptor agonist, that is used over the last years. It has both sedative and analgesic effects.

\section{Objectives}

The scientific objective of the study was to compare dexmedetomidine and midazolam regarding their extubation profile, as well as their cardiovascular response.

\section{Methods}

The present study included forty (40) mechanically ventilated patients of both sexes, aged 20-60 years, who were meeting the standard criteria for weaning. Patients were randomly allocated into 2 groups. Each group included 20 patients $(n=20)$. Patients in group D (Dexmetomidine) received intravenous infusion of dexmedetomidine (0.2-0.7 $\mathrm{mcg} / \mathrm{kg} / \mathrm{h}$ ), while in group M (Midazolam), patients received midazolam $(0.04-0.2 \mathrm{mg} / \mathrm{kg} / \mathrm{h})$ in order to achieve a Ramsay sedation scale of 2-4. Extubation was performed after standard extubation protocol was completed. Time for extubation and vital parameters were recorded periodically.

\section{Results}

Time to extubation in the dexmedetomidine group was significantly lower than in the midazolam group. Blood pressure and heart rate was most of the times significantly lower in the dexmedetomidine group than in the midazolam group. $(\mathrm{p}<0.05)$

\section{Conclusions}

Dexmedetomidine has obvious clinical benefits compared to midazolam regarding extubation. This occurs due to its shorter extubation time, better hemodynamics, easy arousability and lack of respiratory depression.

\section{Authors' details}

${ }^{1}$ Central Clinic of Athens, Research and Treatment Medical Center, Anaesthesiology and Intensive Care, Athens, Greece. 'Evagelismos General Hospital of Athens, Intensive Care Unit, Athens, Greece. ${ }^{3}$ Laiko General Hospital of Athens, University of Athens, Pathophysiology Clinic, Athens, Greece. ${ }^{4}$ Laiko General Hospital of Athens, University of Athens, Intensive Care Unit, Athens, Greece. ${ }^{5}$ University of Athens, Medical School, Neonatology, Athens, Greece. ${ }^{6}$ University of Athens, Medical School, MSc Cardiopulmonary Resuscitation, Athens, Greece.

Published: 1 October 2015

References

1. Kollef MH, Levy NT, Ahrens TS, et al: The use of continuous i.v. sedation is associated with prolongation of mechanical ventilation. Chest 1998, 114:541-8.

2. Soliman HM, Mélot $C$, Vincent JL: Sedative and analgesic practice in the intensive care unit: The results of a European survey. Br J Anaesth 2001, 87:186-92.

3. Jakob SM, Ruokonen E, Grounds RM, et al: Dexmedetomidine vs midazolam or propofol for sedation during prolonged mechanical ventilation: Two randomized controlled trials. JAMA 2012, 307:1151-60.

doi:10.1186/2197-425X-3-S1-A327

Cite this article as: Mavri et al:: Comparison between dexmetomidine and midazolam on early extubation and hemodynamic profile. a randomized double-blind study. Intensive Care Medicine Experimental 2015 3(Suppl 1):A327.

\footnotetext{
${ }^{4}$ Laiko General Hospital of Athens, University of Athens, Intensive Care Unit, Athens, Greece

Full list of author information is available at the end of the article
}

\section{SpringerOpen ${ }^{\odot}$}

(c) 2015 Mavri et al.; This is an Open Access article distributed under the terms of the Creative Commons Attribution License (http:// creativecommons.org/licenses/by/4.0), which permits unrestricted use, distribution, and reproduction in any medium, provided the original work is properly cited. 